\title{
SUB-NATIONAL REGIONAL DEVELOPMENT AND DEGREE- AWARDING TERTIARY EDUCATIONAL INSTITUTIONS IN NIGERIA: DESCRIPTIVE, GEO-DEMOGRAPHIC AND GEO-SPATIAL ANALYSES
}

\author{
Richard INGWE 1), Chibueze C.C. IKEJI 2) , Ude UGWU ${ }^{3)}$ \\ 1) Institute of Public Policy and Administration (IPPA), University of Calabar and Centre for Research and \\ Action on Developing Locales, Regions and the Environment (CRADLE), Calabar, Nigeria \\ 2),3) Institute of Public Policy and Administration (IPPA), University of Calabar, Calabar, Nigeria.
}

\begin{abstract}
Public and private investments in educational institutions as a means of catalysing economic growth has been recognized a veritable strategy for developing human capital, increasing productivity and competitiveness at various regional levels. Nigeria's multiplicity of cultural groups whose political sensitivity to (in)equality in the sharing of nationally pooled resources has been a source of conflicts including the 1967-70 civil war, presents an ideal scenario for understanding the extent of balance or otherwise of tertiary educational opportunities across the national landscape. This has not been sufficiently addressed in the academic literature. This article reports findings of a study of the provision of degree-awarding tertiary educational institutions (TEls) by governments and private entities in Nigeria's sub-national regions. Geo-demographic-spatial and description analyses were used to analyze secondary data. We found among others that: the numbers of TEls provided in the sub-national regions (geo-political zones and their constituent states) have not been determined by the population size of the sub-national regions (state/territory); highest concentration/localisation of TEls were in Nigeria's SouthWest geo-political zone. It is argued that the full government financing of education implemented in the former (South) Western Region about half a century ago (since the 1950s) laid the foundation for creating critically needed human capital mass that has continued to regenerate in multi-dimensional strategies for establishing more TEls thereby promoting regional development in the present South-West Region thereby contrasting with Nigeria's other geo-political regions.
\end{abstract}

Key Words: sub-national region, education, investment, economic growth, human capital, Nigeria

\section{Introduction}

Academic research and policy has recognized the distinctive contributions of tertiary educational institutions including universities and degree-awarding institutions (hereafter described as UDA-TEIs), research-oriented and related institutes, to national research and development (R\&D) efforts, and by extension, the promotion of technical change, which leads to economic growth, social development and progress and advancement of national competitiveness. TEls, especially universities have since their advent functioned to produce human capital (or human power) required in industry, and other institutions of society by training students and staff in addition to providing community services. While the emergence of large and powerful transnational corporations (TNCs) that command enormous financial resources with which they influence and wield political power in advanced countries led to the establishment of privately managed R\&D organizations in some industrial sectors (e.g. pharmaceutical industry), TEls have remained important in promoting most national R\&D efforts. The rise of such private, TNC-related R\&D establishments was part of the factors that led to the suggestion in the mid-1980s that the scientific and technological resources and 
potentials of universities were underutilized. The quest for socio-economic development and improved national competitiveness also led to the assessment of the degree of cooperation, interaction and linkages between universities and industry in the Global North (Stankiewicz 1986).

UDAEIs contribute to the development of cities and rural areas. Owing to the way they attract and sustain populations of considerable sizes comprising students, academic and research workers, visitors, and so forth, TEls contribute to the growth of population within the concentrated areas and promote urbanization. Globally, educational and related services provided by TEls have been instrumental to the achievement of economic, social and environmental change. This happens in various ways. By providing higher knowledge, developing human capita; and skills, and offering cultural services, settlements hosting TEls continuously attract populations searching for these services thereby contribute towards scientific and technological change and catalyzing, cosmopolitanisation of towns and cities. Some TEls assist graduating students to become entrepreneurs by spinning-off firms from their research theses within the environs of the institution (University of Aberdeen, Scotland, 200509). Some TEls in the United States of America have reportedly pioneered the creation and management of biotechnology firms (Geiger 1992, Kenney 1986).

In Nigeria, the establishment of TEls has been one of the central elements of the policy of deliberate urbanization involving the creation of sub-national regional units namely: states and local government areas (LGAs) whose capitals are usually urban centres which are given statutory recognition to receive allocations of public funds for provision of community services and social infrastructure (Mabogunje 1973). Deliberate creation of states by government has mostly been followed by the citing of TEls either within or close to the state capitals. This policy recognizes the distinctive contribution of TEls to the development of the host states in various dimensions. Although, Nigeria's successive constitutions (Nigeria, 1979-2011) have stressed that equitable sharing of opportunities for well-being of citizens is one of the nation's core values, it has been observed that despite the way contest for resources managed by Nigeria's federal government by the nation's multiplicity of ethno-cultural groups has led to conflicts including the 30-month civil war from 1967-1970 (Ladipo, 1989), government policy is yet to seriously strive towards achieving equity among the various sub-national regions as inequality in infrastructural development still reigns supreme (Ingwe, 2011). The extent to which equity is applied in sharing and providing tertiary educational opportunities in Nigeria's sub-national regions is poorly understood.

\section{The problem}

Irrespective of the distinctive contributions of tertiary educational institutions (TEIs) especially universities to human capital development, technical change and by extension socioeconomic development in the Global North, the Global South has needlessly emphasized the importance of natural resources as a strategy of generating national income. Countries of the Global South which have achieved (or are achieving) socioeconomic development more recently (e.g. India) are those which have shifted the policy paradigms from emphasizing natural resource exploitation for export towards human capital development. By relying on the export of crude (petroleum) oil and more recently, export of natural gas, for earning a disproportionately large share of national revenue, Nigeria is one of the best examples of the countries of the Global South that depend on natural resources to achieve socioeconomic development.

Although the contribution of TEls (especially universities) towards increasing the competitiveness of regions has been recognized at the national level, its role in the development of sub-national regions is similar to what obtains nationally. How this has happens 
within federal systems which feature fairly autonomous and independent sub-national governments with great stakes in providing tertiary education involving establishment of TEls that are initiated and managed by state governments remains poorly understood. This is the case in Nigeria, where the contest for the shares of financial and other natural resources pooled together for sharing by a rather highly centralized government led and dominated by the Federal Government to the detriment of other federating tiers has been discredited as the cause of the Nigerian civil war between 1967 and 1970. Moreover, the extent to which other federating tiers of government in Nigeria (especially the 36 states and Federal Capital Territory) have employed universities as means of achieving human capital development and improving their individual competitiveness is poorly understood. Additionally, academic research in Nigeria have treated issues related to universities as separate aspects or topics in the academic fragment of education sector strictly. Such restrictive studies fail to place UDA-TEIs strategically for consideration as vital factors contributing to regional development at various levels. By such practice and thinking, Nigeria's academic research has thus far failed to relate the nation's TEls as a system, their magnitude, distribution by sub-national regions to the wider regional development characteristics of the country.

In this paper, we strive to answer the following questions: What factors have determined human capital development policy response (measured by the total number on degree awarding tertiary educational institutions per sub-national region) in Nigeria? Have the total number of degree awarding tertiary educational institutions (UDA-TEls) per sub-national region (state or territory) been determined by demographic characteristics or have they been determined by specific sub-national regional human capital development policy? We concentrated on degree-awarding institutions and excluded those institutions awarding pre-degree diplomas and certificates. Although such (pre-degree) qualifications are also awarded by TEls, we excluded them from this study only because it was convenient without implying that such qualifications are not important. Inclusion of such pre-degree qualifications is outside the scope of this study.

\section{Objectives}

The objective of this paper is to contribute towards informing public policy on the management of tertiary educational institutions and socio-economic development in (Nigeria). The specific objectives are: To show the number and structure of tertiary educational institutions in Nigeria; and, to describe the spatial and structural characteristics of tertiary educational institutions in Nigeria.

This article is organized in sections. In the remainder of this paper, we present the context for tertiary education in Nigeria, followed by the theoretical framework for the discussion involving elaboration of the human capital theory, and various models for financing education used by different countries. We answer the research question: What factors determine the provision of TEls at Nigeria's sub-national regions by presenting and using geo-demographic and spatial methods to analyse data on: (a) population and (b) tertiary educational institutions covering for the country's 36 states and federal capital. Afterwards, we examine the role of variable subnational policy on education financing in determining the differentiation in TEls across the national landscape. Then, we present and discuss the findings of the study, conclude the article and recommend strategies to improve policy on tertiary education and demographic characteristics. 


\section{Relating the context (rapid rhythm of population growth, poverty, unemployment) to the unmet need for education in Nigeria}

Nigeria's population rose from 88.9 million people in 1991 to over 140 million in 2006. The nation's population has been dominated by younger people aged 0-34 years. Using the medium variant method, the following school age population was projected by 2010 (from the 1991 census); Nursery (age 3-5 years) 14,579,418); primary (age 6-11 years): 25,530,654); junior secondary (age 12-14 years) 14,597,027 and senior secondary (age 15-17 years) 10,017,709), tertiary (age 18-25) 22,137,396 while others (age over 26 years) was 55,343,059 (National population commission 1991). Nigerians have responded to prolonged or nearly chronic poverty afflicting between 70-90 per cent of the population and unemployment/ underemployment as well as a system of employment based almost solely on certificates by massive demand or contest for university and tertiary education. In the past three decades, the number of applications for admission/places in universities especially and other tertiary institutions has always outstripped the vacant places available (Joint Matriculations and Admissions Board (JAMB) Registrar's Reports, National Newspapers and Journals 1990s2009). Therefore, it cans safely be concluded that the need for tertiary education has been unmet in Nigeria.

\section{Tertiary educational attainments in Nigeria (1991)}

The acquisition of tertiary (higher) education by Nigerians aged 6years has been rather low. With a total population of 88.99 million in 1991, Nigeria's population distribution by highest level of education showed that those who had graduated from tertiary institutions were only two per cent $(17,842)$ for polytechnics, and colleges of education; one percent (i.e. 29,277) for universities, and "others (i.e. not specifically or clearly categories; $11 \%(352,689)$. Other levels of education attained were: "senior secondary schools/technical and teachers Training College" was; eight percent $(281,032)$; “junior secondary school/modern": seven per cent $(238,382$; "primary"; $25 \%$ (821,710); "none"; $46 \%(1,517,185)$ and "Not stated" $(0 \%)(16,399)$, (National Population Commission, 1991) (Table 1). Nigeria has been experiencing a high population growth rate as follows: 88,992,220 in 1991 and 140,003,542 in 2006.

Official data reported Nigeria that had 178 university equivalent institutions in 2005, 83 universities in 2006, 10,153 secondary schools in 2006 and 54,434 primary schools in 2006. Enrolment of students and pupils in educational institutions recently was: 810,132 students in universities in 2006; 237,708 students in university equivalent institutions in 2005; 6,909,170 students in secondary schools; and 23,046,766 pupils in primary schools in 2006 . The number of teachers in the institutions were; 26,321 in universities in 2006; 16,499 in university equivalent institutions in 2005; 159,812 in secondary schools in 2006 and 611,750 in primary schools in 2006 (National Bureau of Statistics 2007; 33). With about as large as 28.1 million pupils in the nation's primary schools, combined with the desire to develop human capital, there is every need to be as informed as possible about tertiary educational institutions, which will be in high demand in the near future. What was the level of adequacy (i.e. number of) tertiary educational institutions in Nigeria recently? What has been the recent geographic distribution of tertiary educational institutions in the country?

Planning for improvement of education and human power in Nigeria has had to contend with the following problems since the nation attained political independence from her British Colonialists in 1960: First, appropriate techniques for quantifying required skilled human power; second, the best techniques for determining the optimal resources required for implementing educational programmes. The operationalisation of cost benefit and human power planning 
Sub-national Regional Development and Degree-Awarding Tertiary Educational Institutions in Nigeria: Descriptive, Geo-Demographic and Spatial Analyses

approaches was considered important during the period of reconstruction of Nigeria after the civil war that was fought for about 30 months, between 1967 and 1970 (Ogunsheye 1971: 659).

Educational attainment by Nigerians aged six years and older

\begin{tabular}{l|r|r}
\multicolumn{1}{c|}{ Educational level } & No of graduates & \% of total \\
\hline University & 29,277 & 1 \\
\hline Polytechnic/college of education & 57,842 & 2 \\
\hline SSS/TTC/Tech & 281,032 & 8 \\
\hline JSS/Modern & 238,382 & 7 \\
\hline Primary & 821,710 & 25 \\
\hline None & $1,517,185$ & 46 \\
\hline Others & 352,689 & 11 \\
\hline Not stated & 16,399 & 0 \\
\hline Total & $3,314,516$ & 100
\end{tabular}

Source: Post-Education survey, National population commission, 1991

Some problems hampering national unity in Nigeria are: contest for satisfactory or acceptable shares of resources under the federal system of government, ethnic suspicion and distrust within 440 ethnic linguistic groups identified, specific acts of injustice, unbalanced development with lopsided allocation of resources. Although information on educational institutions is available, they are usually presented in terms of absolute aggregate numbers. There is inadequate information on the magnitude and geographic (spatial) distribution of educational institutions as well as their adequacy for various populations over the national territory. This information gaps hamper proper planning of educational opportunities in ways that the need for education and how to provide the goods and services can be better addressed. To contribute towards addressing the information gap, this article examines the spatial distribution of tertiary educational institutions (TEIs) in Nigeria.

\section{Human capital theory}

There has been an improvement in the perception that formal (or full-time) education (that is based in institutions, and the skills they inculcate into their graduates) contributes immensely towards increasing the welfare of individuals and the region since the middle of the $20^{\text {th }}$ century. However, while the perception that increased schooling (or education) benefits the individual (through improved wages and increased employment opportunities) has increased tremendously and well known to persons and groups, the perception of the benefits or contribution of education to regional development has not attained the level of popularity associated with individuals and families and has been more restricted to particular regions at various levels (countries, sub-national regions e.g. states, provinces, districts, and so forth). Generally, it is believed that increased education creates human capital, that is, causes an improvement in their productivity (or the capability of individual worker and/or group of workers to add value to their personal lives and also those (lives) of their families and societies.

This perception of the value of Human Capital $(\mathrm{HC})$ is more recent and different due to its reference to human beings contrasted to the previous and original conception or association of the key word (capital), which denoted physical capital such as tools, machinery, factory, and so forth). Another reason for the increasing profile of human capital is the way it is being increasingly considered to be one of the most important drivers of other physical capital. However, irrespective of the fact that human capital is relatively more recent compared to the 
conventional capital, its popularity has increased rapidly to the point that the human capital theory was formulated. The theorization of human capital goes beyond the contribution of formal education or schooling and the direct costs associated with it. It includes the perception of workers regarding the acquisition of human capital. Workers believe that human capital is also created through indirect costs associated with the quest of individual workers for improved skills through further training, thereby forfeiting current earnings and consumption as a means of increasing future income and employment chances. This decision that is frequently taken by individuals and group of workers is analogously followed by regions and nations when determining the amount of investment required for education and training necessary for producing the level of human capital required for achieving development goals and objectives. Human capital theory is a variety of the rational choice theory and a modern representation of Adam Smith's (1960 / 1776) explanation of wage differentials based on "net (dis)advantage" among various employments. The net advantage to a worker results from the cost of training for a job or amount of investment in human capital or the quality of education/training undertaken by a worker or group of workers in preparation for a job. Economic growth has been expected to result from widespread or considerable investment in human capital or the production of the desired labour force (i.e. the type that possesses the human resource-base required for producing goods and services) for the society. Some examples have been cited to explain the potency of the contribution of human capital to national and regional development. They include: the rapid reconstruction of some nations that were devastated through military conquest during the Second World War; the rapid industrialization and economic growth achieved by Japan and also more recently, the South-East Asian nations.

Some deficiencies have been identified with the human capital theory. It is difficult to measure some of the concepts (e.g. worker productivity, future income, and the central idea: human capital) associated with it. Improved productivity, as conceived by various employers and /or the labour market, is not guaranteed by all investments in education-one of the major sources of human capital. The discussion of worker productivity - a major issue in the human capital theory- tautologically refers to actual differentials in earnings, the same point that the theory sets out to explain. Owing to the high proportion of variance in actual earnings, although some of this could be resulting from variation in skills, it has been suggested that the imperfect structure and functioning of the labour market play important roles, in addition to those attributed to worker productivity differentials. Despite the criticisms associated with the human capital theory, it is relevant to the field of education generally, and also to related fields such as the sociology of education and training (Smith 1960; Scott and Marshall 2005: 279; Kalra 2006: 155).

\section{Educational Financing}

This term describes a framework or system of generating, sharing or allocating, and spending revenue to provide education in a region (be it country, province, state or other entities which undertake the responsibility). It includes directions, policies, revenue appropriation mechanisms adopted for pursuing objectives and goals of the education system. It involves the following activities; formulating and forecasting suitable revenue generation and expenditure strategies; Elaborating and rationalizing various methods of generating, allocating and disbursing the available revenue or funds; establishing a system for clarifying various patterns of fund flows that form foundations for educational financial control and accounting; establishing rational bases for deciding on the stakeholders or strata of the society to bear the burden of financing education and also providing required goods and services; designing appropriate systems that are rational, efficient for accounting and control required for managing resources in the education system or institutions and divisions. 


\section{Models for Financing Education}

Three major theories of educational financing have been addressed towards answering questions; what is the most suitable formula for sharing the burden of providing education among stakeholders or strata of the society including; households, workers, companies, communities and so on? What financial mechanisms would be best suited for achieving the objectives of region's education system while minimizing or eliminating disruptions? We present the three major theories below.

Full Government financing of Education. John Undie (2007) traces the origin of this theory to Morrison Morpet's argument in 1974. It advocates that the public sector should bear full responsibility for financing education for the immense benefit of both the individual and the entire society. This is to ensure that none of those who seek to be educated is denied a chance to achieve such noble aspiration. It is frequently enshrined in the nation's legal document especially the constitution thereby clarifying the level of type of education that citizens in need should get or be given. It is usually associated with central governments which are considered to be most strategically positioned to generate funds, control and manage programmes, institutions in ways that the goals and objectives of education can be achieved. Other levels of government (district, provincial or state and municipality), are under this model, not expected to play the major role that is expected from national government. Some advantages have been associated with it. It is seen as a means of Equalization of educational opportunities for most groups of citizens forming the nation (e.g. ethnic or racial communities, regions etc thereby reducing inequality in socio-economic terms. It is considered to be an instrument for ensuring that sharing of resources among national constituencies (groups) is implemented without conflicts, disruptions and disagreement. By so doing, it is believed to justify and reward all constituencies for the contribution (egg tax) and rate burdens that they bear. It also satisfies educational needs of the constituents. It has been criticized for being resource intensive and demanding by people who are unduly emphasizes scarcity of resources. Some claim that it fails to reward people who contribute more the most through tax by allocating to them a commensurate share of the educational goods and services purchased with their contributions. The resource scarcity critique of the model has also stressed it in appropriateness under Structural Adjustment Programmes SAP in developing countries (Undie 2007:52). This critique turns out to be weak considering the recent unpopularity of structural adjustment policies (SAPs) across sub-Saharan Africa and more recent collapse of the Washington consensus variety of neoliberalism as shown by the 2008 global financial meltdown that rapidly culminated in the global economic recession (Brand and Sekler 2009).

Partial Government Financing Model. This framework involves the financing of education by all stakeholders or constituents of the society including households, companies and government.

There are two kinds of this model as described below:

- A partial government financing of education designed to equals socioeconomic conditions of the population (Cubberly 1906). Cubberly's theory, which has remained popular for over a century is considered to be one of the pioneering advocacy for state-public financing of education, emphasized fairness to various groups in the society.

- $\quad$ The Strayer-Haig equal access model was aimed at employing state instruments to accomplish equalization of educational opportunities for all who need an education. It emphasized the use of uniform effort and standards to ensure that every child who needs education gets it within the confine of the nation - state implementing 
the policy. Implementation of uniform tax burden on parents and guardians of children requiring education was proposed as the appropriate mechanism for guaranteeing educational financing (Strayer and Haig 1923: 173). Districts \& communities within a nation implementing this model are allowed and encouraged to augment central government resource allocations as a way of raising educational standards within their jurisdictions. This allowance poses a problem; it promotes competitiveness through the increased quality of education permitted. Then it contradicts the equalization of educational opportunities earlier desired.

Private Financing Model. This model proposes that private entities (firms, organizations etc) rather than the government should finance education. The complete exclusion of government from the financing of education is justified by the "confidence" reposed on the ability of market forces (demand and supply) to use prince mechanism as determinants of the price to buy and sell education. One of the most prominent critiques of this model is based on the recurrent problems (collapse) of the market system. Education is widely perceived as very important to be left to the vagaries of market system-where it is bound to suffer serious damage that society cannot afford.

The Government financing (both full and partial) have been more frequently adopted and praised due to several reasons: Education is widely perceived as social goods and services which bring about immense benefits to the society including citizens and the government. Moreover, benefits derived from education are considered to be external (to the individual who receives it), therefore its acquisition is commonly recommended to be made universally i.e. to be shared widely among citizen rather that restrict it through privatization. The private investment model is perceived to be susceptible to under investment - a situation that makes government financing inevitable to raise the standard for the society. The rich, their children and wards stand to gain much more than the poor majority when education is privatized. The resulting exclusion of the poor majority leads to problems in the society, economy and polity. Inability of most people to gain skills and knowledge renders them unemployable and reduces their entrepreneurial capability. Increasing unemployable breeds social and political disruptions and conflicts.

Government financing of education facilitates large-scale investment and derivation of economies of scale: through taxation, government raises revenue to finance and manage institutions required for implementing education programmes. The private sector is limited and therefore resorts to the application of limited resources, providing small-scale resources to establish the required goods and services to provide bases for educational programmes (Undie 2007:52-57).

\section{Social capital investment at the sub-national regional scale}

The role of sub national regional investment in social capital development as a means of stimulating economic growth and competitiveness has been acknowledged for nearly half a century- by regional economists. Benjamin Chinitz argued that regional economic growth was largely determined by local production of entrepreneurs and the rate or willingness of the entrepreneurs to perceive and to exploit existing opportunities. He contended that some opportunities may not be visible, while entrepreneurs may not be as mobile as would be necessary to size opportunities existing outside their usual places of residence and work. More importantly, he argued that the flow of entrepreneurs (and their talent) and the historical occurrence and cumulative effects of this played a key role in causing regional development. The failure of a region to stimulate development through investment in education, and related 
processes (egg industrial manufacturing, commerce etc) required for raising the quality of the local population suffers huge losses of entrepreneurs: Apart from not producing enough of entrepreneurs, the few available are prone to out migration to other regions possessing the prerequisites for seizing and exploiting economic growth-inducing opportunities. This leads to steady decline in productivity beneath levels that would have been achievable if conditions were more favourable.

Chinitz also argued that the national market is not the plat form where entrepreneurs and growth opportunities contend or confront each other as some used to think. Instead, sub national regions provided refreshing and new platforms. The contribution of regional-based entrepreneurs to the gross national product is significant in determining the total size. Entrepreneurship was the underlying factor, hindered as it has been by its variability by region, its friction or mobility problems over space; local development stimulus or incentives. The more the number of competent entrepreneurs, the more likely high are the chances of their seizure of existing business (and by extension economic growth) opportunities (Chinitz 1966).

Previously, the significance of entrepreneurship had been documented. It was distinguished from labour (one of the three factors of production; land, labour and capital, thus making it to stand alone and separately-under the capitalist market system. (Olaore 1980: 129). Entrepreneurial talent has been credited with determining the degree to which manufacturing (establishments and activities) localized in a particular city (region) and by extension its variation over space-based on studies of the United State of America. This applies to the specialization of certain cities (regions) in the manufacture of specific products. The role of entrepreneurship in shaping development, generally, and national economic development, in particular, has been acknowledged by several scholars (Hall 1902, Schumpeter 1949, Cole 1955, Parker 1954, and Ranis 1955).

While the pursuit of national development in some countries still unduly emphasis natural resources (such as petroleum oil, natural gas and minerals), a new paradigm has emerged that places high premium on human capital. It was recently estimated that human capital (describing the national or regional stock of people equipped with education, skills from training, and good/sound health) contributes about 75 percent (i.e. three quarter) of the wealth possessed by a modern economy. The remainder ( 25 per cent) could be derived from other sources including physical capital accounts, infrastructure and so forth (The national scholar: editorial 2002:1). In recognition of its distinctively important contribution to national and regional economic growth, human capital has been described as a new factor of production that scholars who earlier identified land, labour and capital (contrasted to human capital) ignored or were unable to perceive.

The acquisition or creation of human capital has been credited to gaining of experience, greater knowledge, skills and other abilities competencies required for building economic success. It has been stressed that mere educational institutions is not enough for creating human capital (Obadina 2007: 49). More evidence has been provided to illustrate or buttress the importance of human capital to economic growth. A recent survey of the quality and return to workforce from 27 countries revealed that the most popular nations where foreign work talents are sourced (sought) are: USA, China, and India, Mexico \& the Philippines. Some of these countries are the largest recipients of remittances by the human capital possessors as follows: China (US\$ 25:7 billion). Indian workers demanded from abroad include: engineers, nurses, construction specialists and drivers. India has been on the list of the world's top 10 fastest (economically) growing countries (http://www.siliconindia.com/shownews/43078). 
Although they are not the sole contributors or determinants of human capital development, educational institutions provide required foundations for gaining further skills, knowledge and talent that form human capital. Therefore, knowledge of educational institutions in a particular region is necessary for determining their (in) adequacy for producing the needed workforce or human power. Moreover, knowledge of the geographic (spatial) distribution of educational institutions cover the region or nation helps to clarify issues pertaining to justice, fairness, balanced development and social order required for ensuring peaceful environment that is devoid of rancour, disagreement and conflict.

\section{Methods}

We used a combination of methods: geo-demographic, including spatial analysis, and description. The methods of geo-demography and spatial analyses involve the use of the welldeveloped but simple geometric "language" that scientists have employed to better understand problems that could be expressed over geographic space, uses metrical units to measure distances based on the Euclidean space concept.

This concept refers to space that is based on the Euclid and is measured in metrical units. It has been recognized by philosophers of science as providing a suitable form of measurement of physical distance on terra firma. Euclidian space has offered geographic research both advanced as well as simple geometric "language" that provides tremendous value (Harvey 1969). Therefore, it is presented as a multi- (that is, two or more) dimensional scheme for analyzing problems and phenomena that are amenable to representation in geospatial formats or a framework that possesses geographical references such as coordinates (latitudes and longitudes). For example, the first two dimensions of a Euclidian space conceptual framework designed to resolve a geographical problem comprises the distance between the two axes in space namely: " $x$ " and " $y$ ". The remaining two dimensions could be: " $z$ ", which denotes magnitude of a feature, or event (e.g. demography i.e. population and its characteristics), while another axis, "t" could describe time over which the event of interest occurred or the feature developed (Harvey 1969). The relevance of this concept of space to geographic analysis and the increasing frequency of its application by geographers in analyzing myriad of development problems has made this spatial analysis to become synonymous with geography and studies that are considered to be geographic (i.e. spatial) in the literature. Therefore, the term spatial is commonly used to describe the application of geographic space meaning the distribution of things (features, phenomena and so forth) on the earth's surface (Demers, 1999).

The amenability of this concept for constructing multiple dimensions of problems thereby facilitating analysis makes it suitable for this study. It is also useful in the analysis of spatial (i.e. geographic) distribution or sharing of things (features, objectives, events and so forth) over an area (Harvey 1969: 223-226, Demers 2000: 485). In this study the "thing" of our concern was the distribution of universities and degree awarding institutions while the spatial units were constituted or represented by sub-national regions (36 states and federal capital, Abuja). In order to answer the question concerning the extent to which demographic factors are considered in the formulation of policies regarding human capital development and the establishment of degree awarding tertiary educational institutions, we employed the geodemographic methodology. This comprises the application of: (a) geographic information science, a variant of geographic information systems (GIS) that involves advanced modeling of geographic datasets representing variables endowed with spatial attributes); (b) spatial analysis and, (c) spatial analytic tools. The methods facilitate the development of sophisticated statistical techniques for analyzing datasets that concentrate on demographic variables including distributions of human population in geographic space and their interactions or inter- 
relationships with other development issues. The application of geo-demographic analysis has reportedly led to immense improvement in the performance of commerce and for-profit activities by marketers of goods and services in the United States of America and elsewhere (Goss 1995). Demography defines the scientific study of human populations including their size, composition, distribution, density, growth and the population's other social, economic, and political characteristics within a delimited territory or region (National Population Commission (Nigeria 1990) adds value to information for policy.

We also used the method of description to show the structure of the universities and degree awarding tertiary educational institutions (UDA-TEls) thereby highlighting their properties or attributes in terms of their general type, area of concentration namely; conventional, technological, agricultural, ownership (e.g. by federal, state, private individuals and/or organizations and other entities. This classification is necessary for creating logical relationship required for modeling the distribution in a way that the reality can be more accurately represented in a clear way (Lipschutz 1986:1-2). This was also necessary for creating and applying a simple database system required for computing and producing information of interest for achieving the objectives of this study.

\section{Data and sources}

We obtained and used data from secondary sources namely the Joint Admissions and Matriculation Board (JAMB), which is Nigeria's official agency responsible for producing and publishing "Guidelines for Admissions to First Degree Courses in Nigerian Universities and other Degree Awarding Institutions" (JAMB 2008/2009). Population data were extracted from the most recent census of population and housing conducted in 2006 by another official agency: the National Population Commission. Data collected by these official agencies are considered as reliable and have been widely used for research. Considering that the original data were not explicit and could not graphically show the spatial distribution of the degree awarding institutions and their characteristics, we undertook to process them as a way of transforming them into information, from which knowledge could be produced.

\section{Data processing and analysis}

We reorganized the data and produced matrices that included a column for depicting the spatial units representing the sub-national regions constituting Nigeria namely; the 36 states and federal capital territory, Abuja. Our geo-demographic analysis involved computation of per capita quotients of available degree awarding tertiary educational institutions in each of the sub -national regions by dividing their total number existing in each of the sub-national regions during the 2008=09 academic session by the regions' population in 2006 . We perceived the total population as convenient for the computation by assuming that the benefits of tertiary educational institutions accrue to various strata of the total population: either directly as students or indirectly as parents, employers, among other relationships. The values of the resulting quotients (column "d", table 2) were ranked in order to highlight variations in such opportunities by state/territory.

Other columns were produced to represent the structure of the universities and degree awarding institutions (type including; ownership by tier of government or private sector). The cells (boxes) within the matrices were used to show the frequency of occurrence of the institutions by type, characteristics or structure (see Tables 2 and 3). While the foregoing operation elucidated on the consideration of demographic and population factors in providing 
tertiary educational institutions, it was limited in clarifying variations in sub-national regional policies on human capital development.

Therefore, we used the six geo-political zones created and applied since the 1990s for most resource sharing programmes in Nigeria as a framework for classifying each of the spatial units (states and territory) (Fig.1 and Fig.2) into their respective geopolitical regions thereby facilitating the description of the regional characteristics of the degree awarding tertiary educational institutions. The purpose was to highlight the localization of the universities and degree awarding institutions within the various constituent geopolitical zones in the country. The other structural aspects of the institutions (type, ownership) were retained or repeated in this matrix (see Table 3). The aim was to inform about the expression or distribution of these properties and attributes at the geopolitical zones level.

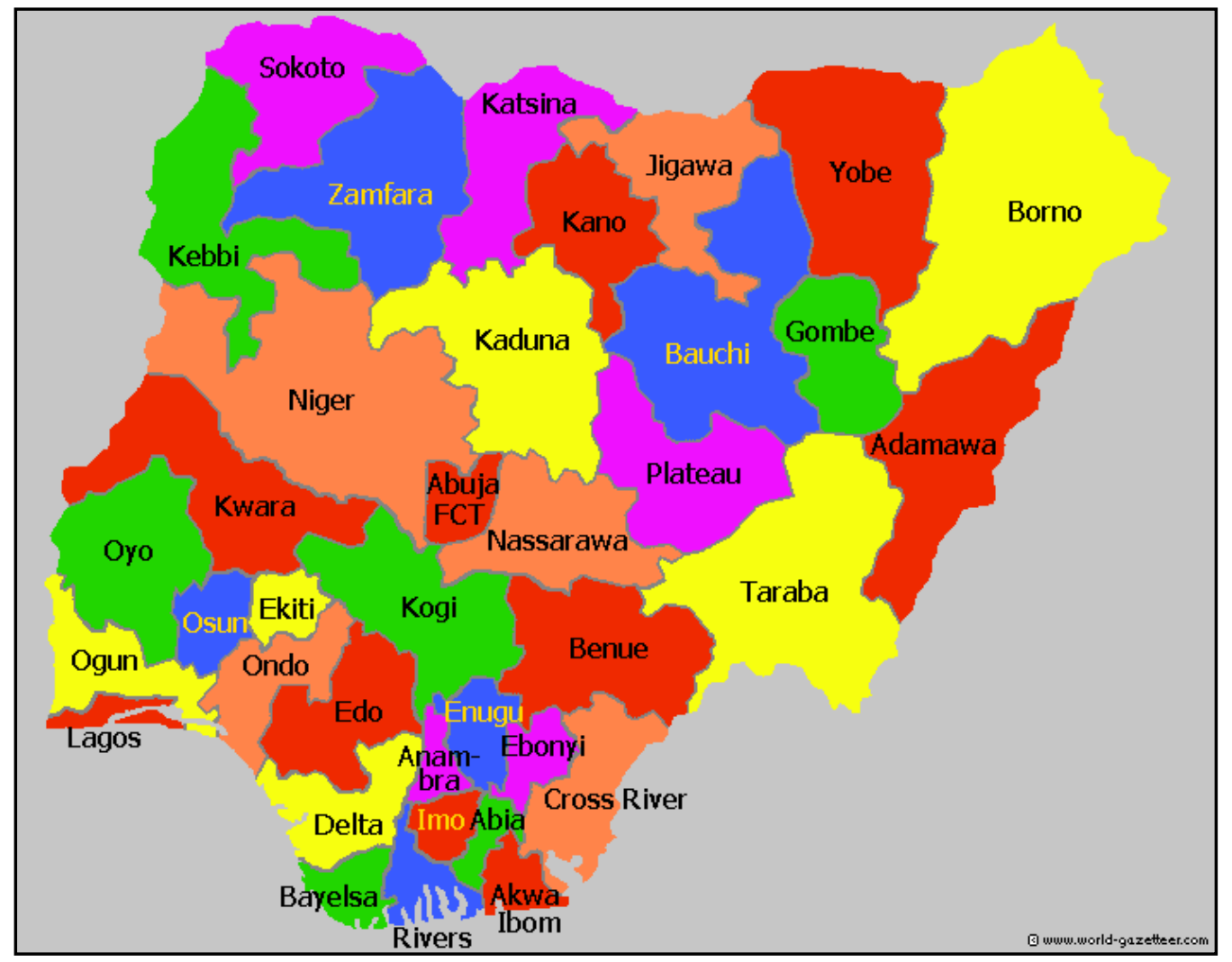

Fig.1 - Nigeria: 36 Federal States and Federal Capital Territory, Abuja

\section{Findings and Discussion}

Have the total number of degree awarding tertiary educational institutions per sub-national region (state or territory) been determined by demographic characteristics?

The extent to which population is considered in providing tertiary educational institutions in 
Nigeria's states/territory might be best illustrated by reference to some of the states which exhibit contrasts in terms of the correspondence of demography and number of TEls available to the population. Examination of the relationship between the population of Nigeria's 36 states, FCT and their respective numbers of TEls (columns $b$ and $c$ respectively of table?) shows that the number of the latter does not follow the size of the former. While some states with large populations have low number of TEls (e.g. Kano Nigeria's most populous state 9383,682 persons in 2006 had only three TEls), other less populated states (Ogun state whose population of 3728,098 in 2006 was less than half of the population of Kano yet had as high as seven TEIs).

\section{Per capita quotients of number of degree awarding tertiary educational institutions for the population by sub-national regions (states and federal capital territory, Abuja)}

The foregoing point is more clearly represented by results of computation of the shares (quotients) of TEls available to the various populations of the sub-national regions (column $d$ of table 2). The most outstanding of the lack of correspondence of number of TEls available to sub-national regional populations could be illustrated by some states. For example, while Kano state, located in the northern part of Nigeria, Nigeria's most populated sub-national region (with 9383,682 persons) in 2006, it had only three TEls translating into a per capita quotient of (3.20 $X 10^{-7}$ ) in 2008-09. State policy contrasts to the Kano state scenario could be illustrated with some states. First, Ogun state whose population in 2006 of 3728,098 was less than half of that of Kano had as high as seven TEls translating into a per capita quotient of $\left(1.88 \times 10^{-6}\right)$ in 2008-09. The second contrast to Kano is Lagos (the second most populous Nigerian state: $9013,534)$ and had seven TEls translating into a per capita quotient of $\left(7.77 \times 10^{-7}\right)$. The profuse exhibition of this lack of correspondence between population size and number of TEls in other Nigerian states (including: southeastern state: Anambra; north central state: Kaduna; etc) is shown in details in table?

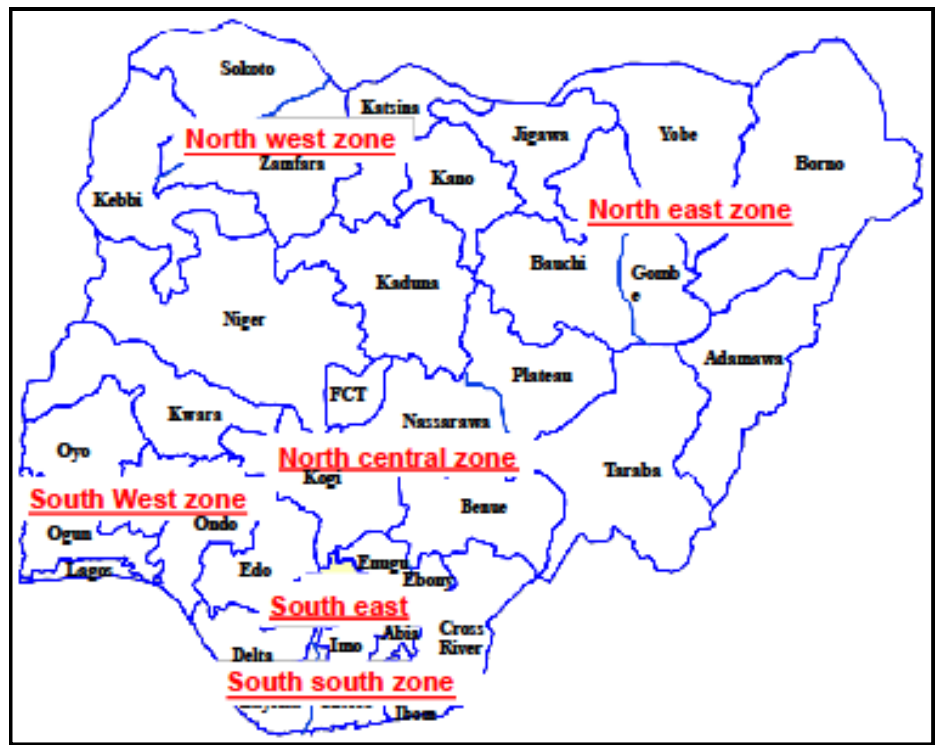

Fig.2 - Nigeria's Geopolitical Zones 


\section{Geo-demography and number of UDA-TEls by sub-national region}

\begin{tabular}{|c|c|c|c|c|}
\hline a. State/Territory & $\begin{array}{l}\text { b. Population } \\
(2006)\end{array}$ & $\begin{array}{l}\text { c. Total } \\
\text { number of DA- } \\
\text { TEls in sub- } \\
\text { national } \\
\text { regions }\end{array}$ & $\begin{array}{l}\text { d. Per capita } \\
\text { TEls /state }\end{array}$ & $\begin{array}{l}\text { e. Rank of SNR } \\
\text { Based on value of } \\
\text { per capita TEls }\end{array}$ \\
\hline Abia & $2,833,999$ & 3 & $1.05857 \mathrm{E}-06$ & 10 \\
\hline Adamawa & $3,168,101$ & 2 & 6.31293E-07 & 17 \\
\hline Akwa Ibom & $3,920,208$ & 2 & $5.10177 \mathrm{E}-07$ & 23 \\
\hline Anambra & $4,182,032$ & 7 & 1.67383E-06 & 5 \\
\hline Bauchi & $4,676,465$ & 1 & $2.13837 \mathrm{E}-07$ & 35 \\
\hline Bayelsa & $1,703,358$ & 3 & 1.76123E-06 & 3 \\
\hline Benue & $4,219,244$ & 1 & 2.37009E-07 & 34 \\
\hline Borno & $4,151,193$ & 2 & 4.81789E-07 & 24 \\
\hline Cross River & $2,888,966$ & 4 & $1.38458 \mathrm{E}-06$ & 7 \\
\hline Delta & $4,098,391$ & 1 & $2.43998 \mathrm{E}-07$ & 33 \\
\hline Ebonyi & $2,173,501$ & 4 & $1.84035 \mathrm{E}-06$ & 2 \\
\hline Edo & $3,218,332$ & 2 & $6.2144 \mathrm{E}-07$ & 18 \\
\hline Ekiti & $2,384,212$ & 3 & $1.25828 \mathrm{E}-06$ & 8 \\
\hline Enugu & $3,257,298$ & 1 & 3.07003E-07 & 32 \\
\hline Gombe & $2,353,879$ & 1 & 4.24831E-07 & 27 \\
\hline Imo & $3,934,899$ & 3 & $7.62408 \mathrm{E}-07$ & 14 \\
\hline Jigawa & $4,348,649$ & 0 & 0 & 36 \\
\hline Kaduna & $6,066,562$ & 4 & 6.59352E-07 & 16 \\
\hline Kano & $9,383,682$ & 3 & 3.19704E-07 & 29 \\
\hline Katsina & $5,792,578$ & 2 & 3.45269E-07 & 28 \\
\hline Kebbi & $3,238,628$ & 1 & 3.08773E-07 & 31 \\
\hline Kogi & $3,278,487$ & 2 & $6.10037 \mathrm{E}-07$ & 20 \\
\hline Kwarra & $2,371,089$ & 2 & 8.43494E-07 & 12 \\
\hline Lagos & $9,013,534$ & 7 & 7.7661E-07 & 13 \\
\hline Nasarawa & $1,863,275$ & 3 & 1.61007E-06 & 6 \\
\hline Niger & $3,950,249$ & 4 & 1.01259E-06 & 9 \\
\hline Ogun & $3,728,098$ & 7 & $1.87763 \mathrm{E}-06$ & 1 \\
\hline Ondo & $3,441,024$ & 2 & 5.81222E-07 & 19 \\
\hline Osun & $3,423,535$ & 6 & $1.75257 \mathrm{E}-06$ & 4 \\
\hline Oyo & $5,591,589$ & 5 & 8.942E-07 & 11 \\
\hline Plateau & $3,178,712$ & 1 & 3.14593E-07 & 30 \\
\hline Rivers & $5,185,400$ & 3 & $5.78547 \mathrm{E}-07$ & 21 \\
\hline Sokoto & $3,696,999$ & 2 & 5.40979E-07 & 22 \\
\hline Taraba & $2,300,736$ & 1 & 4.34644E-07 & 26 \\
\hline Yobe & $2,321,591$ & 1 & 4.30739E-07 & 25 \\
\hline Zamfara & $3,259,846$ & 0 & 0 & 37 \\
\hline FCT (Abuja) & $1,405,201$ & 1 & 7.11642E-07 & 15 \\
\hline Total (Nigeria) & & $97 / 97$ & $6.9284 \mathrm{E}-07$ & National average \\
\hline
\end{tabular}

Notes: DA = Degree awarding

Sources: Authors' computation from data obtained from Nigeria's Federal government Report of 2006 Census by National Population Commission 2007 and the JAMB 2008/9. 
Sub-national Regional Development and Degree-Awarding Tertiary Educational Institutions in Nigeria: Descriptive, Geo-Demographic and Spatial Analyses

Table 3

Spatial distribution of tertiary institutions by states and tertiary

\begin{tabular}{|c|c|c|c|c|c|c|c|c|c|}
\hline & & $\begin{array}{l}\text { Federal } \\
\text { conven- } \\
\text { tional } \\
\text { universi- } \\
\text { ties }\end{array}$ & $\begin{array}{l}\text { Agricul- } \\
\text { tural } \\
\text { Federal } \\
\text { universi- } \\
\text { ties }\end{array}$ & $\begin{array}{l}\text { Federal } \\
\text { universi- } \\
\text { ties of } \\
\text { Techno- } \\
\text { logy (FUT) }\end{array}$ & $\begin{array}{l}\text { State } \\
\text { conven- } \\
\text { tional } \\
\text { univer- } \\
\text { sities }\end{array}$ & $\begin{array}{l}\text { State } \\
\text { tech- } \\
\text { no- } \\
\text { logy } \\
\text { univer } \\
\text { sities }\end{array}$ & $\begin{array}{l}\text { Private } \\
\text { univer- } \\
\text { sities }\end{array}$ & $\begin{array}{l}\text { Others } \\
\text { Degree } \\
\text { Awarding } \\
\text { institu- } \\
\text { tions }\end{array}$ & $\begin{array}{l}\text { Total of } \\
\text { all } \\
\text { degree } \\
\text { Awarding } \\
\text { Institu- } \\
\text { tions }\end{array}$ \\
\hline 1 & Abia & & $\begin{array}{l}1 \\
\text { (Umudike) }\end{array}$ & & $\begin{array}{l}\text { 1(Uturu), } \\
\text { ABSU) }\end{array}$ & & & $\begin{array}{l}\text { 1(Ogbor } \\
\text { Hill, Aba }\end{array}$ & 3 \\
\hline 2 & Adamawa & & $\begin{array}{l}\text { 1(Yola, } \\
\text { FUT Yola }\end{array}$ & & & & 1 Yola & & 2 \\
\hline 3 & $\begin{array}{l}\text { Akwa } \\
\text { Ibom }\end{array}$ & $\begin{array}{l}1 \\
\text { (UniUyo) }\end{array}$ & & & & & $\begin{array}{l}1 \text { (Obong } \\
\text { Ntak) }\end{array}$ & & 2 \\
\hline 4 & Anambra & $\begin{array}{l}1(\mathrm{NAU}) 1 \\
(\mathrm{UNN})\end{array}$ & & & & $\begin{array}{l}\text { 1(Uli, } \\
\text { Anam } \\
\text { Tech }\end{array}$ & $\begin{array}{l}1 \text { (Okija) } \\
1 \text { (Oba) }\end{array}$ & $\begin{array}{l}1 \\
\text { (Onitsha), } \\
\text { (Awka) }\end{array}$ & 7 \\
\hline 5 & Bauchi & & $\begin{array}{l}\text { 1(Bauchi, } \\
\text { TBU) }\end{array}$ & & & & & & 1 \\
\hline 6 & Bayelsa & & & & $\begin{array}{l}1 \\
\text { (Yenagoa) } \\
\text { NDU }\end{array}$ & & 1 (Mkar) & & 3 \\
\hline 7 & Benue & & 1(Makurdi) & & 1(Makurdi) & & & & 1 \\
\hline 8 & Borno & $\begin{array}{l}1 \\
\text { (UniMaid) }\end{array}$ & & & & & & & 2 \\
\hline 9 & $\begin{array}{l}\text { Cross } \\
\text { River }\end{array}$ & 1(UniCal & & & $\begin{array}{l}1(\mathrm{X}- \\
\text { Calabar, } \\
\text { CRUTCH) }\end{array}$ & & $\begin{array}{l}1 \text { (Kwale) } \\
1 \\
\text { (Oghara) }\end{array}$ & & 4 \\
\hline 10 & Delta & & & $\begin{array}{l}\text { 1(Effurun, } \\
\text { UniPetrol } \\
\text { Resources }\end{array}$ & 1(Abraka) & & & & 1 \\
\hline 11 & Ebonyi & & & & $\begin{array}{l}1 \\
\text { (Abakaliki) }\end{array}$ & & $\begin{array}{l}\text { 1(Benin), } \\
1 \text { (Benin) }\end{array}$ & & 4 \\
\hline 12 & Edo & $\begin{array}{l}1 \\
\text { (UniBen) }\end{array}$ & & & $\begin{array}{l}\text { 1(Ekpoma } \\
\mathrm{AAU})\end{array}$ & & & $\begin{array}{l}1 \text { (Ikere- } \\
\text { Ekiti) }\end{array}$ & 2 \\
\hline 13 & Ekiti & & & & $\begin{array}{l}\text { 1(Ado- } \\
\text { Ekiti, } \\
\text { UNAD) }\end{array}$ & & $\begin{array}{l}\text { 1(Amorji- } \\
\text { Nike } 1 \\
\text { (Ojiagu } \\
\text { Agbasi }\end{array}$ & & 3 \\
\hline 14 & Enugu & & & & & $\begin{array}{l}1 \\
\text { (Enugu, } \\
\text { ESU) }\end{array}$ & & & \\
\hline
\end{tabular}


Richard INGWE, Chibueze C.C. IKEJI, Ude UGWU

\begin{tabular}{|c|c|c|c|c|c|c|c|c|}
\hline & $\begin{array}{l}\text { Federal } \\
\text { conven- } \\
\text { tional } \\
\text { univer- } \\
\text { sities }\end{array}$ & $\begin{array}{l}\text { Agricul- } \\
\text { tural } \\
\text { Federal } \\
\text { univer- } \\
\text { sities }\end{array}$ & $\begin{array}{l}\text { Federal } \\
\text { universi- } \\
\text { ties of } \\
\text { Techno- } \\
\text { logy } \\
\text { (FUT) }\end{array}$ & $\begin{array}{l}\text { State } \\
\text { conven- } \\
\text { tional } \\
\text { univer- } \\
\text { sities }\end{array}$ & $\begin{array}{l}\text { State } \\
\text { techno- } \\
\text { logy } \\
\text { univer- } \\
\text { sities }\end{array}$ & $\begin{array}{l}\text { Private } \\
\text { univer- } \\
\text { sities }\end{array}$ & $\begin{array}{l}\text { Others } \\
\text { Degree } \\
\text { Awarding } \\
\text { institu- } \\
\text { tions }\end{array}$ & $\begin{array}{l}\text { Total of } \\
\text { all degree } \\
\text { Awarding } \\
\text { Institu- } \\
\text { tions }\end{array}$ \\
\hline 15 Gombe & & & & $\begin{array}{l}\text { 1(Tudun- } \\
\text { Wada) }\end{array}$ & & & & 1 \\
\hline 16 Imo & & & $\begin{array}{l}1 \text { (Owerri, } \\
\text { FUTO) }\end{array}$ & $\begin{array}{l}\text { 1(Owerri, } \\
\text { MSU) }\end{array}$ & & & 1(Owerri) & 3 \\
\hline 17 Jigawa & & & & & & & & 0 \\
\hline 18 Kaduna & $1(\mathrm{ABU})$ & & & $\begin{array}{l}1 \\
\text { (Kaduna, } \\
\text { KASU) }\end{array}$ & & & $\begin{array}{l}\text { 1(Zaria), } 1 \\
\text { (Kaduna) }\end{array}$ & 4 \\
\hline 19 Kano & 1 (BUK) & & & $\begin{array}{l}\text { 1(Kano, } \\
\text { KSUST) }\end{array}$ & & & 1(Kano) & 3 \\
\hline 20 Katsina & & & & 1(Katsina) & & $\begin{array}{l}1 \\
\text { (Katsina) }\end{array}$ & & 2 \\
\hline 21 Kebbi & & & & & $\begin{array}{l}\text { 1(Aliero, } \\
\mathrm{K}\end{array}$ & & & 1 \\
\hline 22 Kogi & & & & $\begin{array}{l}1 \\
\text { (Anyigba, } \\
\text { Kosu) }\end{array}$ & & 1(Lokoja) & & 2 \\
\hline 23 Kwara & $\begin{array}{l}\text { (Un } \\
\text { Ilorin) }\end{array}$ & & & & & 1(Ilorin) & & 2 \\
\hline 24 Lagos & $\begin{array}{l}1 \\
\text { (UniLag) }\end{array}$ & & & $\begin{array}{l}\text { 1(Ojo, } \\
\text { LASU) }\end{array}$ & & $\begin{array}{l}\text { 1(lkeja) } 1 \\
\text { (Lag) } 1 \\
\text { (Ikeja) }\end{array}$ & $\begin{array}{l}\text { 1(Yaba, } 1 \\
\text { (Yaba) }\end{array}$ & 7 \\
\hline $\begin{array}{l}25 \text { Nasaraw } \\
\text { a }\end{array}$ & & & & 1 (Keffi) & & 1(Karu) & 1(Akwanga) & 3 \\
\hline 26 Niger & & & $\begin{array}{l}\text { 1(FUT } \\
\text { Minna ) }\end{array}$ & $\begin{array}{l}\text { 1(Lapai, } \\
\text { IBBU) }\end{array}$ & & & $\begin{array}{l}\text { 1(Minna), } 1 \\
\text { (Kontagora) }\end{array}$ & 4 \\
\hline 27 Ogun & & $\begin{array}{l}1 \\
\text { (Abeoku } \\
\text { ta) }\end{array}$ & & $\begin{array}{l}\text { 2(Ago- } \\
\text { Iwoye, }\end{array}$ & & $\begin{array}{l}\text { 1(Ota), } 1 \\
\text { (Ota), } 1 \\
\text { (Igbosa) } \\
\text { 1(Abeo- } \\
\text { kuta) }\end{array}$ & & 7 \\
\hline 28 Ondo & & & & $\begin{array}{l}1 \\
\text { (Akungba } \\
\text {-Akoka) }\end{array}$ & & & 1(Ondo) & 2 \\
\hline
\end{tabular}


Sub-national Regional Development and Degree-Awarding Tertiary Educational Institutions in Nigeria: Descriptive, Geo-Demographic and Spatial Analyses

\begin{tabular}{|c|c|c|c|c|c|c|c|c|c|}
\hline & & $\begin{array}{l}\text { Federal } \\
\text { conven- } \\
\text { tional } \\
\text { universi- } \\
\text { ties }\end{array}$ & $\begin{array}{l}\text { Agricul- } \\
\text { tural } \\
\text { Federal } \\
\text { univer- } \\
\text { sities }\end{array}$ & $\begin{array}{l}\text { Federal } \\
\text { univer- } \\
\text { sities of } \\
\text { Techno } \\
\text {-logy } \\
\text { (FUT) }\end{array}$ & $\begin{array}{l}\text { State } \\
\text { conven- } \\
\text { tional } \\
\text { univer- } \\
\text { sities }\end{array}$ & $\begin{array}{l}\text { State } \\
\text { techno- } \\
\text { logy } \\
\text { univer- } \\
\text { sities }\end{array}$ & $\begin{array}{l}\text { Private } \\
\text { univer- } \\
\text { sities }\end{array}$ & $\begin{array}{l}\text { Others } \\
\text { Degree } \\
\text { Awarding } \\
\text { institu- } \\
\text { tions }\end{array}$ & $\begin{array}{l}\text { Total of all } \\
\text { degree } \\
\text { Awarding } \\
\text { Institu- } \\
\text { tions }\end{array}$ \\
\hline & Osun & $1(\mathrm{OAU})$ & & & & & $\begin{array}{l}\text { 1(Iwo), } 1 \\
\text { (Osogou), } \\
\text { 1(Ikeji } \\
\text { Arakeji) }\end{array}$ & $\begin{array}{l}1 \text { (llesa), } 1 \\
\text { (lla- } \\
\text { Orangu) }\end{array}$ & 6 \\
\hline & Oyo & $1(\mathrm{Ui})$ & & & & $\begin{array}{l}1 \\
\text { (Ogbomo } \\
\text { sho) LAU } \\
\text { Tech }\end{array}$ & $\begin{array}{l}\text { 1(Oyo), } 1 \\
\text { (Ibadan) }\end{array}$ & 1(Ibadan) & 5 \\
\hline 31 & Plateau & 1(UniJos) & & & & & & & \\
\hline 32 & Rivers & $\begin{array}{l}1 \\
\text { (UniPort) }\end{array}$ & & & & $\begin{array}{l}1 \text { (Port } \\
\text { Harcourt) } \\
\text {, RSUST }\end{array}$ & & $\begin{array}{l}1 \text { (Port } \\
\text { Harcourt) }\end{array}$ & 3 \\
\hline 33 & Sokoto & 1(UDUni) & & & & & & 1(Sokoto) & 2 \\
\hline & Taraba & & & & & & 1(Wukari) & & 1 \\
\hline & Yobe & & & & $\begin{array}{l}1 \\
\text { Damaturu }\end{array}$ & & & & 1 \\
\hline & Zamfara & & & & & & & & 0 \\
\hline 37 & $\begin{array}{l}\text { Abuja } \\
\text { FCT }\end{array}$ & 1(Abuja) & & & & & & & 1 \\
\hline & $\begin{array}{l}\text { Total } \\
\text { (Nigeria) }\end{array}$ & 16 & 3 & 5 & 21 & 5 & 28 & 19 & $97 / 97$ \\
\hline
\end{tabular}

Sources: JAMB (Joint Admissions and Matriculation Board 2008/2009 UME/DE Brochure Guidelines for admissions to first degree courses in Nigerian universities and others Degree Awarding Institutions (in Nigeria): 13-17.

The frequency (number of universities and degree awarding institutions) in the states/territory in descending order is presented below (table 4).

\section{Number of UDA-TEls in various states and territory}

Three states had the highest number (seven) of UDAls, one state had six, one also had five and 16 had four. Twenty one states had three UDAls; 18 had two, 10 had one each and two had none. 


\begin{tabular}{|c|c|c|c|}
\hline \multicolumn{4}{|c|}{ Representation of the number of UDA-TEls in various states and territory } \\
\hline \multicolumn{2}{|c|}{ No of U\&DAls } & \multirow{2}{*}{$\begin{array}{c}\text { States/territory in the } \\
\text { category }\end{array}$} & \multirow{2}{*}{$\begin{array}{c}\text { Territory no of } \\
\text { states }\end{array}$} \\
\hline 8 & $\begin{array}{l}\text { No of UDAls X No of } \\
\text { states/territory }\end{array}$ & & \\
\hline 7 & $7 \times 3=21$ & Anambra, Ogun \& Lagos & 3 \\
\hline 6 & $6 \times 1=6$ & Osun & 1 \\
\hline 5 & $5 \times 1=5$ & Oyo & 1 \\
\hline 4 & $4 \times 4=16$ & $\begin{array}{l}\text { Edo, Delta, Kaduna, } \\
\text { Niger, }\end{array}$ & 4 \\
\hline 3 & $3 \times 7=21$ & $\begin{array}{l}\text { Abia, Benue, Enugu, } \\
\text { Imo, Kano, Nasarawa, } \\
\text { and Rivers }\end{array}$ & 7 \\
\hline 2 & $2 \times 9=19$ & $\begin{array}{l}\text { Adamawa, Akwa-lbom, } \\
\text { Cross River, Ekiti, } \\
\text { Katsina, Kogi, Kwara, } \\
\text { Ondo, \& Sokoto }\end{array}$ & 9 \\
\hline 1 & $1 \times 10=10$ & $\begin{array}{l}\text { Bauchi, Bayelsa, Borno, } \\
\text { Ebonyi, Gombe, Kebbi, } \\
\text { Plateau, Taraba, Yobe, } \\
\text { \& Abuja FCT. }\end{array}$ & 10 \\
\hline 0 & $0 \times 2=0$ & Jigawa and Zamfara & 2 \\
\hline $\begin{array}{l}\text { Grand } \\
\text { Total }\end{array}$ & 97 & & 38 \\
\hline
\end{tabular}

Source: Computed by authors from data obtained from reliable official sources

\section{Localization or concentration of UDA-TEls in Nigeria's six geopolitical zones}

The concentration of all types of UDAls, by absolute number and percentage, in descending order of magnitude in the six geopolitical zones was as follows (Fig.2). The South-West (geopolitical zone had 29.9 per cent (i.e. the largest number) of all the institutions in the country. This was followed by the North Central zone with 18 (or 18.56 per cent); the SouthEast with 17 (or 17.53 per cent); South-South with 16 (or 16.5 per cent); North-West with 10 (or 10.31 per cent) and North-East with 14 (or 7.22 per cent).

Federal Conventional Universities (FCUs). The concentration of FCUs in descending order of magnitude was as follows: four FCUs (the largest number) in the South-South zone; three in the North-West, North-Central and South-West; two in the South East; and one in the NorthEast.

Federal Agricultural Universities. The distribution of federal agricultural universities (FAUs) in descending order of magnitude was; one in the North-Central, South-West and South-East. None was located in the South-South, North-East and North-Central. 
Sub-national Regional Development and Degree-Awarding Tertiary Educational Institutions in Nigeria: Descriptive, Geo-Demographic and Spatial Analyses

Federal Universities of Technology (FUTs). The concentration of FUTs in descending order of magnitude was as follows: two (largest number) in the North-East; one in four geopolitical zones (North-Central, South-West, South-East and South-South) and none in the North-West.

State (Conventional) Universities (SCUs). The distribution of conventional universities established and managed by state governments in descending order of magnitude was; highest (six) in the South-West; five in the North-Central and South-South; three in the SouthEast and two each in the North-West and North- East.

State (Technological) Universities (STUs). State universities of technology established and managed by state governments were concentrated in descending order of magnitude as follows: two in the South-East; and one in the North-West. None were reported in the SouthSouth, South-West, North-Central and North-East zones.

Private Universities. Private universities were concentrated, in descending order of magnitude, as follows: 12 in the South-West; five each in the North-Central and South-South; four in the South-East and only one in the North-East.

Other Degree Awarding Institutions (ODAls). The ODAls were concentrated in descending order of magnitude, as follows: seven in the South-West; four each in the North-West and South-East; three in the North-Central, and one each in the North-East and South-South.

Table 5

Localization of UDA-TEls in Nigeria's six geopolitical zones

\begin{tabular}{|c|c|c|c|c|c|c|c|c|c|c|}
\hline & & $\begin{array}{l}\text { Federal } \\
\text { conven- } \\
\text { tional } \\
\text { univer- } \\
\text { sities }\end{array}$ & $\begin{array}{l}\text { Agricul- } \\
\text { tural } \\
\text { Federal } \\
\text { univer- } \\
\text { sities }\end{array}$ & $\begin{array}{l}\text { Federal } \\
\text { univer- } \\
\text { sities of } \\
\text { Techno- } \\
\text { logy }\end{array}$ & $\begin{array}{l}\text { State } \\
\text { conven- } \\
\text { tional } \\
\text { univer- } \\
\text { sities }\end{array}$ & $\begin{array}{l}\text { State } \\
\text { tech- } \\
\text { no- } \\
\text { logy } \\
\text { univer } \\
\text { sities }\end{array}$ & $\begin{array}{l}\text { Private } \\
\text { univer- } \\
\text { sities }\end{array}$ & $\begin{array}{l}\text { Others } \\
\text { Degree } \\
\text { Awarding } \\
\text { institu- } \\
\text { tions }\end{array}$ & $\begin{array}{l}\text { Total } \\
\text { (All U\& } \\
\text { DAIS }\end{array}$ & $\begin{array}{l}\% \text { of } \\
\text { Total }\end{array}$ \\
\hline & $\begin{array}{l}\text { North } \\
\text { East }\end{array}$ & 1 & & 2 & 2 & & 1 & 1 & 7 & 7.22 \\
\hline 1 & Adamawa & & & 1 & & & & 1 & 2 & \\
\hline 2 & Bauchi & & & 1 & & & & & 1 & \\
\hline 3 & Borno & 1 & & & & & & & 1 & \\
\hline 4 & Gombe & & & & 1 & & & & 1 & \\
\hline 5 & Taraba & & & & & & 1 & & 1 & \\
\hline 6 & Yobe & & & & 1 & & & & 1 & \\
\hline & Sub-total & & & & & & & & 14 & \\
\hline & $\begin{array}{l}\text { So u t h - } \\
\text { South (B) }\end{array}$ & 4 & 1 & 5 & & & 5 & 1 & & 16.5 \\
\hline 1 & Akwa Ibom & 1 & & & & & 1 & & 2 & \\
\hline
\end{tabular}


Richard INGWE, Chibueze C.C. IKEJI, Ude UGWU

\begin{tabular}{|c|c|c|c|c|c|c|c|c|c|c|c|}
\hline & & $\begin{array}{l}\text { Federal } \\
\text { conven- } \\
\text { tional } \\
\text { univer- } \\
\text { sities }\end{array}$ & $\begin{array}{l}\text { Agricu } \\
\text { tural } \\
\text { Federa } \\
\text { univer- } \\
\text { sities }\end{array}$ & $\begin{array}{l}\text { Federal } \\
\text { univer- } \\
\text { sities of } \\
\text { Techno- } \\
\text { logy }\end{array}$ & & $\begin{array}{l}\text { State } \\
\text { conven- } \\
\text { tional } \\
\text { univer- } \\
\text { sities }\end{array}$ & $\begin{array}{l}\text { State } \\
\text { tech- } \\
\text { no- } \\
\text { logy } \\
\text { univer } \\
\text { sities }\end{array}$ & $\begin{array}{l}\text { Private } \\
\text { univer- } \\
\text { sities }\end{array}$ & $\begin{array}{l}\text { Others } \\
\text { Degree } \\
\text { Awarding } \\
\text { institu- } \\
\text { tions }\end{array}$ & $\begin{array}{l}\text { Total } \\
\text { (All U\& } \\
\text { DAIS }\end{array}$ & $\begin{array}{l}\% \text { of } \\
\text { Total }\end{array}$ \\
\hline 2 & Bayelsa & & & & & $1^{*}$ & & & & 1 & \\
\hline 3 & $\begin{array}{l}\text { Cross } \\
\text { River }\end{array}$ & 1 & & & & $1^{*}$ & & & & 2 & \\
\hline 4 & Delta & & & & 1 & 1 & & 2 & & 4 & \\
\hline 5 & Edo & 1 & & & & 1 & & 2 & & 4 & \\
\hline \multirow[t]{3}{*}{6} & Rivers & 1 & & & & 1 & & & 1 & 3 & \\
\hline & Sub-total & & & & & & & & & 16 & \\
\hline & $\begin{array}{l}\text { South- } \\
\text { East }\end{array}$ & 2 & & & 1 & 3 & 2 & 4 & 4 & 17 & 17.53 \\
\hline 1 & Abia & & & & & 1 & & & 1 & 3 & \\
\hline 2 & Anambra & 2 & & & & & 1 & 2 & 2 & 7 & \\
\hline 3 & Ebonyi & & & & & 1 & & & & 1 & \\
\hline 4 & Enugu & & & & & & 1 & 2 & & 3 & \\
\hline \multirow[t]{3}{*}{5} & Imo & & & & & 1 & & & 1 & 3 & \\
\hline & Sub-total & & & & & & & & & & \\
\hline & $\begin{array}{l}\text { South- } \\
\text { West (C) }\end{array}$ & 3 & & & 1 & 6 & & 12 & 7 & 29 & 29.90 \\
\hline 1 & Ekiti & & & & & 1 & & & 1 & 2 & \\
\hline 2 & Lagos & 1 & & & & 1 & & 3 & 2 & 7 & \\
\hline 3 & Ogun & & & & & 2 & & 4 & & 7 & \\
\hline 4 & Ondo & & & & 1 & 1 & & & 1 & 2 & \\
\hline 5 & Osun & 1 & & & & & & 3 & 2 & 6 & \\
\hline \multirow[t]{3}{*}{6} & Oyo & 1 & & & & 1 & & 2 & 1 & 5 & \\
\hline & Sub-total & & & & & & & & & & \\
\hline & $\begin{array}{l}\text { North- } \\
\text { West (D) }\end{array}$ & 3 & & & & 2 & 1 & & 4 & 10 & 10.31 \\
\hline 1 & Jigawa & - & & & - & - & - & 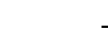 & - & 0 & \\
\hline 2 & Kaduna & 1 & & & & 1 & & & 2 & 4 & \\
\hline 3 & Kano & 1 & & & & $1^{*}$ & & & 1 & 3 & \\
\hline 4 & Kebbi & & & & & & 1 & & & 1 & \\
\hline 5 & Sokoto & 1 & & & & & & & 1 & 2 & \\
\hline 6 & Zamfara & - & - & 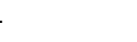 & - & - & - & - & - & 0 & \\
\hline
\end{tabular}


Sub-national Regional Development and Degree-Awarding Tertiary Educational Institutions in Nigeria: Descriptive, Geo-Demographic and Spatial Analyses

\begin{tabular}{|c|c|c|c|c|c|c|c|c|c|c|c|}
\hline & & $\begin{array}{l}\text { Federal } \\
\text { conven- } \\
\text { tional } \\
\text { univer- } \\
\text { sities }\end{array}$ & $\begin{array}{l}\text { Agricul- } \\
\text { tural } \\
\text { Federal } \\
\text { univer- } \\
\text { sities }\end{array}$ & $\begin{array}{l}\text { Federal } \\
\text { univer- } \\
\text { sities of } \\
\text { Techno- } \\
\text { logy }\end{array}$ & & $\begin{array}{l}\text { State } \\
\text { conven- } \\
\text { tional } \\
\text { univer- } \\
\text { sities }\end{array}$ & $\begin{array}{l}\text { State } \\
\text { tech- } \\
\text { no- } \\
\text { logy } \\
\text { univer } \\
\text { sities }\end{array}$ & $\begin{array}{l}\text { Private } \\
\text { univer- } \\
\text { sities }\end{array}$ & $\begin{array}{l}\text { Others } \\
\text { Degree } \\
\text { Awarding } \\
\text { institu- } \\
\text { tions }\end{array}$ & $\begin{array}{l}\text { Total } \\
\text { (All U\& } \\
\text { DAIS }\end{array}$ & $\begin{array}{l}\% \text { of } \\
\text { Total }\end{array}$ \\
\hline & \multicolumn{11}{|l|}{ Sub-total } \\
\hline & $\begin{array}{l}\text { North- } \\
\text { Central } \\
\text { (E) }\end{array}$ & 3 & 1 & & 1 & 5 & & 5 & 3 & 18 & 18.56 \\
\hline 1 & Benue & & 1 & & & 1 & & 1 & & 3 & \\
\hline 2 & Katsina & & & & & 1 & & 1 & & 2 & \\
\hline 3 & Kogi & & & & & 1 & & 1 & & 2 & \\
\hline 4 & Kwara & 1 & & & & & & 1 & & 2 & \\
\hline 5 & Nasarawa & & & & & 1 & & 1 & 1 & 3 & \\
\hline 6 & Niger & & & & 1 & & & & 2 & 4 & \\
\hline 7 & Plateau & 1 & & & & & & & & 1 & \\
\hline 8 & $\begin{array}{l}\text { FCT, } \\
\text { Abuja }\end{array}$ & 1 & & & & & & & & 1 & \\
\hline & \multicolumn{11}{|l|}{ Sub-total } \\
\hline & Total & & & & & & & & & & 97.1 \\
\hline
\end{tabular}

Notes: * Despite inclusion of the term "technology" in their names, JAMB put them under conventional (traditional) universities.

\section{Ranks of the six geo-political zones in terms of provision of UDA-TEls under the context of the regional population characteristics}

The ranking of states based on the geo-political zones that they belong to shows that the states under the North-East zone had the following ranks: Adamawa (17), Bauchi (35), Borno (24), Gombe (27), Taraba (26), and Yobe (25). The states constituting the South-South geo-political zone achieved the following ranks: Akwa Ibom (23), Bayelsa (3), Cross River (7), Delta (33), Edo (18), and Rivers (21). Two of the six states in this zone were ranked in the top ten, one in the top 20, while the remainder (three) were in the $21^{\text {st }}-33^{\text {rd }}$ position. The ranks of the SouthEast states were: Abia (10), Anambra (5), Ebonyi (2), Enugu (32), and Imo (14). The SouthWest states contained as much as $29.90 \%$ of the total number of UDA-TEls in Nigeria and were some of the highest as they ranked between Ogun (1), Ekiti (8), Lagos (13), Osun (4), and Oyo (11) and Ondo (19). This is the only region that had up to three states whose ranks were in the top ten positions and the other three in the top 20. The states in the North-West were ranked thus: Jigawa (36), Kaduna (16), Kano (29), Kebbi (31), Sokoto (22), and Zamfara (37). The North-Central geo-political zone which has the highest number of states and territory, the ranks were as follows: Benue (34), Katsina (28), Kogi (20), Kwara (12), Nasarawa (6), Niger (9), Playeau (30) and the FCT (15). 
The way population size has been ignored in the provision of the UDA-TEls is most conspicuously demonstrated by the computation, comparison or relation to the percent population of the sub-national regions and their constituent states (Table 6). It shows that the sub-national regions with the highest numbers of UDA-TEls were not those hosting the largest population. For example, while the percent population of Nigeria's total residing in the SouthWest $(19.7 \%)$ was exceeded by that in the North West $(21.4 \%)$, the former had a higher percent $(29.9 \%)$ of the total UDA-TEls than the latter $(10.3 \%)$.

Table 6

Ranks of sub-national geo-political zones with their constituent states/territory

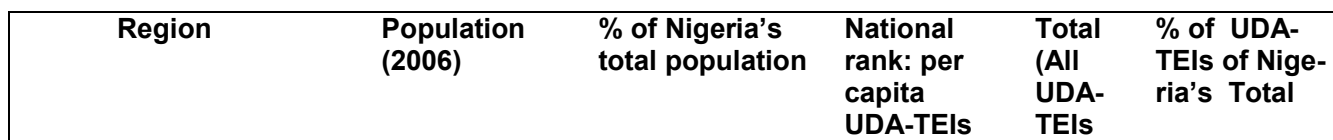

\begin{tabular}{|c|c|c|c|c|c|c|}
\hline & North-East & 18971968 & 13.6 & & 7 & 7.2 \\
\hline 1 & Adamawa & $3,168,101$ & 2.3 & 17 & 2 & \\
\hline 2 & Bauchi & $4,676,465$ & 3.3 & 35 & 1 & \\
\hline 3 & Borno & $4,151,193$ & 3.0 & 24 & 1 & \\
\hline 4 & Gombe & $2,353,879$ & 1.7 & 27 & 1 & \\
\hline 5 & Taraba & $2,300,736$ & 1.6 & 26 & 1 & \\
\hline 6 & Yobe & $2,321,591$ & 1.7 & 25 & 1 & \\
\hline & South-South (B) & 21014655 & 15.0 & & 17 & 16.5 \\
\hline 1 & Akwa Ibom & $3,920,208$ & 2.8 & 23 & 2 & \\
\hline 2 & Bayelsa & $1,703,358$ & 1.2 & 3 & 1 & \\
\hline 3 & Cross River & $2,888,966$ & 2.1 & 7 & 2 & \\
\hline 4 & Delta & $4,098,391$ & 2.9 & 33 & 4 & \\
\hline 5 & Edo & $3,218,332$ & 2.3 & 18 & 4 & \\
\hline 6 & Rivers & $5,185,400$ & 3.7 & 21 & 3 & \\
\hline & South-East & 16381729 & 11.7 & & 17 & 17.5 \\
\hline 1 & Abia & $2,833,999$ & 2.0 & 10 & 3 & \\
\hline 2 & Anambra & $4,182,032$ & 3.0 & 5 & 7 & \\
\hline 3 & Ebonyi & $2,173,501$ & 1.6 & 2 & 1 & \\
\hline 4 & Enugu & $3,257,298$ & 2.3 & 32 & 3 & \\
\hline 5 & Imo & $3,934,899$ & 2.8 & 14 & 3 & \\
\hline & South-West (C) & 27581992 & 19.7 & & 29 & 29.9 \\
\hline 1 & Ekiti & $2,384,212$ & 1.7 & 8 & 2 & \\
\hline 2 & Lagos & $9,013,534$ & 6.4 & 13 & 7 & \\
\hline 3 & Ogun & $3,728,098$ & 2.7 & 1 & 7 & \\
\hline 4 & Ondo & $3,441,024$ & 2.5 & 19 & 2 & \\
\hline 5 & Osun & $3,423,535$ & 2.4 & 4 & 6 & \\
\hline 6 & Oyo & $5,591,589$ & 4.2 & 11 & 5 & \\
\hline & North-West (D) & 29994366 & 21.4 & & 10 & 10.3 \\
\hline 1 & Jigawa & $4,348,649$ & 3.1 & 36 & 0 & \\
\hline 2 & Kaduna & $6,066,562$ & 4.3 & 16 & 4 & \\
\hline 3 & Kano & $9,383,682$ & 6.7 & 29 & 3 & \\
\hline 4 & Kebbi & $3,238,628$ & 2.3 & 31 & 1 & \\
\hline 5 & Sokoto & $3,696,999$ & 2.6 & 22 & 2 & \\
\hline 6 & Zamfara & $3,259,846$ & 2.3 & 37 & 0 & \\
\hline
\end{tabular}


Sub-national Regional Development and Degree-Awarding Tertiary Educational Institutions in Nigeria: Descriptive, Geo-Demographic and Spatial Analyses

\begin{tabular}{|c|c|c|c|c|c|c|}
\hline & Region & $\begin{array}{l}\text { Population } \\
(2006)\end{array}$ & $\begin{array}{l}\% \text { of Nigeria's } \\
\text { total population }\end{array}$ & $\begin{array}{l}\text { National } \\
\text { rank: per } \\
\text { capita } \\
\text { UDA-TEls }\end{array}$ & $\begin{array}{l}\text { Total } \\
\text { (All } \\
\text { UDA- } \\
\text { TEls }\end{array}$ & $\begin{array}{l}\% \text { of UDA- } \\
\text { TEls of Nige- } \\
\text { ria's Total }\end{array}$ \\
\hline & North-Central (E) & 26058817 & 18.6 & & 18 & 18.6 \\
\hline 1 & Benue & $4,219,244$ & 3.0 & 34 & 3 & \\
\hline 2 & Katsina & $5,792,578$ & 4.1 & 28 & 2 & \\
\hline 3 & Kogi & $3,278,487$ & 2.3 & 20 & 2 & \\
\hline 4 & Kwara & $2,371,089$ & 1.7 & 12 & 2 & \\
\hline 5 & Nasarawa & $1,863,275$ & 1.3 & 6 & 3 & \\
\hline 6 & Niger & $3,950,249$ & 2.8 & 9 & 4 & \\
\hline 7 & Plateau & $3,178,712$ & 2.3 & 30 & 1 & \\
\hline 8 & FCT, Abuja & $1,405,201$ & 1.0 & 15 & 1 & \\
\hline & Total & $140,003,542$ & 100.00 & & & $97.1 \%$ \\
\hline
\end{tabular}

Notes:* Despite inclusion of the term "technology" in their names, JAMB put them under conventional (traditional) universities.

\section{Sub-national regional human capital development policy and number of UDA-TEls in Nigeria}

The extent to which sub-national regional policy on educational financing has determined the variability in availability of TEls in the different geopolitical zones of Nigeria was explained by A. Babs Fafunwa, the nation's foremost educationist who is regarded as the father of education in the country. The variation emerged during the era of self-determination in development generally and in education in particular when Nigeria operated three (and later four) geopolitical zones between 1951 and 1970. Although the military dictatorship led by General Yakubu Gowon created 13 states as a means of promoting unity among the nation's multiplicity of ethnic groups in 1967, the eruption of a civil war in that year did not allow the existing development planning and management culture to based on the four sub-national regions to get altered radically by the new geopolitical configuration until the war ended in 1970. It was during that era of self determination that the (south) Western Region under the leadership of its Premier: Obafemi Awolowo broke with the past education policy by introducing free and universal primary education. Although, other Regions (North and East) followed the pioneering example by the Western Region to establish a university for their respective regions, Awolowo's free education programme among other deep education policies enabled the region to achieve higher enrolments in institutions. He established the University of Ife, as a regionally owned and managed institution thereby adding to the existing University of Ibadan, earlier established in the 1940s by Nigeria's national government. The Western Region's education programme has been described as one of the boldest, most unprecedented and most comprehensive education schemes in sub-Saharan Africa. This is because of the way it comprised massive establishment of various types of secondary schools (technical, grammar, teacher training, modern, etc and the serious efforts that were made to meet the deadline for completing the projects that was fixed for January 1955. The setting up of the Banjo Commission by the Western Region, six years after introducing the free universal education programme enabled the region's government to learn and to improve upon the policy including the introduction of various laudable educational innovations. By 1963, the Ajayi Commission Report helped the Western Region government to overhaul the education system (Fafunwa, 2004: 189-192, Fafunwa 1967). During Nigeria's second and fourth Republics (1979-1983 and 1999-present), Awolowo's political legacy of free universal education has been perpetuated by governors who adopt and apply his policy. The continuing implementation of this treasured 
localized policy in the South Western states (Lagos, Ogun, Ondo, Oyo, and Ekiti). The implementation of this policy of greater or full government financing of education has enabled the Yoruba to receive free education and thereby advance beyond the educational attainments of other geo-political regions. In other words, the policy has assisted the Yoruba to become Nigeria most highly \& largely educated tribe in the country with the highest numbers of educated/trained human power in various professions- from journalism, law, accounting, scientists to engineering among others. It is widely and frequently stated in education-speak in Nigeria that one of the South-West states (Ekiti) has the highest number of university professors in Nigeria. None of Nigeria's other five geo-political zones has adopted the freeeducation policy that became customary in the South-West since the 1950s. The extant literature reports that scandalous corruption has been depriving masses of Nigeria's poor citizenry of financial and other resources that could have been used for human capital development such as health-care, education, etc (Smith 2007, Omojola 2007, Ribadu 2009). Further research could hypothesize that the higher educational attainment in the South-West serves as a means of curbing corruption in the human capital development aspect in the SouthSouth through checks and pressure provided by educated people.

\section{Limitations of the study}

Institutions awarding pre-degree diplomas and certificates (such as ordinary and higher diplomas, certificates of education, agriculture, information and communications technologies, among several others) were excluded from this study due to convenience. A more comprehensive (preferably better funded study is required to elucidate on the contribution of these institutions towards compensating for the deficit in degree-awarding institutions in the sub-national regions studied.

\section{Conclusion and policy implications}

The results of this study has shown that the policy of governments and other organizations providing tertiary education in Nigeria at sub-national regions have ignored demographic factors and failed to tackle the problem of inequality in opportunities for advancement of various cultural groups constituting Nigeria. Instead such policies have been determined by the perception of individual states/territory of the value or contribution of human capital to sustainable development. The study's findings that south western Nigeria has the highest number of TEls have been linked to the extant literature that credits greater achievement in education to the pioneering emphasis of the Obafemi Awolowo premiership of the region on educational development. This policy was continued by successive governments of the western region, which have done this in political opposition to the federal government from the 1950s up to the present. Owing implementation of full government financing of education in the region in the 1950s, the largest pool of social and human capital created from the policy has created a legacy of placing high premium on tertiary education. This is demonstrated by the findings that the region has been in creasing the number of tertiary institutions via a combination of private and public financing models. The huge turn out of human capital resulting therefore should provide lessons for the rest of Nigeria's states and territory to emulate. While this study informs policy on universities and degree awarding institutions there is need further studies on the graduation of professionals and scholars in various subjects to improve understanding of specific disciplines and areas of human capital development by states and geopolitical regions to inform targeted policy on development.

Considering that human capital development has been used as a strategy for achieving greater sustainable economic growth in several countries (e.g. North America, Western Europe, Asia, 
etc), Nigeria's state governments would do their regions good by investing more on creation and management of TEls while restraining the federal government from promoting inequity in providing TEls. Moreover, there is need for the state governments to mobilize other stakeholders providing UDA-TEls to consider addressing imbalances and demand for UDA-TEls, where deficits exist. Further research should explore the relationship between the magnitude of tertiary educational institutions and human capital development programmes and their contribution to economic growth generally, and specifically entrepreneurial development and cognate issues in Nigeria. Further analysis/description of the contribution of the federal government of Nigeria to the imbalance in providing TEls is required for refining policy.

Acknowledgment

The authors are grateful for the useful comments of anonymous reviewers of an earlier version of the manuscript which was refined to produce this paper.

\section{References}

BRAND, U., SEKLER, N. (eds.), (2009), Postneoliberalism: A beginning debate, Development Dialogue, (Uppsala); V6.51, January.

CUBBERLY ELWOOD, P. (1906), School Funds and their Apportionment, Teachers College Press, New York.

CHINITZ, B. (1966), Appropriate Goals for regional economic policy, Urban Studies, Vol.5 No.1, February: 1-7.

COLE, A. H. (1955), A New set of stages: Explorations in entrepreneurial History, Vol. 8 ,

No. 2, December: 99-107.

DEMERS, M. (2000), Fundamentals of Geographic Information systems (2ed), John Wiley \& Sons, New York.

FAFUNWA, A. B. (1967), A History of Nigeria Higher Education: New Perspectives in African Education, MacMillan, London \& Lagos. Ltd., Ibadan.

FAFUNWA, A. B. (2004), History of Education in Nigeria, NPS Educational Publishers

GEIGER, R. L. (1992), The Ambiguous Link: Private Industry and University Research, in William E. Becker \& Darrell R. Lewis (eds.) The Economics of American Higher Education, M.A. Kluwer Academic Publishers, Boston.

GOSS, J. (1995), We know where you are, we know where you live: The instrumental rationality of geodemographic systems, Economic Geography, 72 (2), April.

HAGGETT, P. (1992), Geography: a modern synthesis, Harper \& Row, New York.

HALL, Fr. S. (1902), The Localization of Industries, Twelfth Census of the United States (of America) manufacturing part 1, US Government Printing officer: CXC-CCXIV, Washington, DC.

HARVEY D. (1969), Explanation in Geography, Arnold, London, http:// www.siliconindia.com/shownews/43078.

INGWE, R. (2011), Development policy, marginalisation, and sub national regional integration toward economic diversification and poverty reduction in Nigeria: Comparing road infrastructure development in Nigeria's six geopolitical zones, (Unpublished paper on file in the Centre for Research and Action on Developing Locales, regions and the Environment, CRADLE, Calabar).

Joint Admission and Matriculations Board (JAMB) 2008/2009 University Matriculation Examinations /Direct Entry (Brochure) Guidelines for admissions to first degree courses in Nigerian universities and others Degree Awarding Institutions (in Nigeria). Abuja: JAMB.

Delhi. KALRA, K.P. (2006), Academic's Dictionary of Economics, Academic Publishers, New 
KENNEY, M. (1986), Biotechnology: The University-Industrial Complex, Yale University Press, New Haven, CT .

LADIPO, O.O. (1989), Nigerian Economic Development and International Externalities,

Inaugural Lecture Series, No. 79, Obafemi Awolowo University Press Ltd., Ile-Ife. LIPSCHUTZ, S. (1986), Data structures, McGraw Hill Book Co., New York. MABOGUNJE, A.L. (1972), Cities and social order, Oxford University Press, Ibadan. Nigeria, Federal Government of (1960), Federal Government Commission on Post-

School Certificate \& Higher Education in Nigeria, in Education (The Ashby Report), Ministry of Education, Lagos.

National Population Commission (1991), Nigeria at A glance, Abuja/Lagos, National Population Commission. National Bureau of Statistics (2007), The Nigerian Statistical Fact Sheets On Economic and Social Development, Abuja, National Bureau of Statistics. National Population Commission (1990), 1990 Diary, Lagos, National Population Commission. National Scholar (The) (2002), Insight the national scholar, September, 1. Nigeria, Federal Republic of (2011), Ammended Constitution of the Federal Republic of Nigeria, No publishers, Nigeria. Nigeria, Federal Republic of (1999), Constitution of the Federal Republic of Nigeria, Federal Government Printers Lagos. OBADINA, T. (2007), The Global Human capital Divide, Africa Today, Vol. 13, No. 10, October: 48-9. OGUNNIYI, M.B. (1992), Understanding Research in the Social Sciences, University Press PLC, Ibadan. OGUNSHEYE, A. (1971), Education and manpower, in: A. A. Ayida and H.M.A. Onitiri (eds). Reconstruction and Development in Nigeria (proceedings of a National Conference) Oxford University Press, Ibadan. OLAORE, G.O. (1980), The loss indicator As a tool of regional development strategy:

An Exploratory Study of Ogun State, in: E.C. Ndekwu (ed). Proceedings of NISER Staff Seminar, Nigerian Institute of Social and Economic Research (NISER), Ibadan: 128-156. OMOJOLA, B. (2007), The Niger Delta: Rich, but very poor, (A Special Report), AfricaToday, October: 20-39. PARKER, W. N. (1954), Explorations in Entrepreneurial History, Vol.7, No1, October: 26 $-36$.

RANIS, G. (1955), The Community-Centred Entrepreneur in Japanese Development, Explorations in Entrepreneurial History, Vol.8, No2, December: 80-89. RIBADU, N. (2009), Corruption: The Nigeria Example (I), (Address to the US House of

Representatives in May 2009), THE WEEK (Lagos), vol. 29, no. 13, 1 June: 50. RIBADU, N. (2009), Corruption: The Nigeria Example (II), (Address to the US House of

Representatives in May 2009), THE WEEK (Lagos), vol. 29, no. 14, 8 June: 50. SCHUMPETER, J. A. (1949), The Theory of Economic Development, Mass: Harvard University Press, Cambridge. SCOTT, J., MARSHALL, G. (2005), Oxford Dictionary of Sociology, Oxford University Press, Oxford.

SMITH, A. (1960), An inquiry into the Nature and Causes of the Wealth of Nations, Vol. I \& II, Representation of original publications in 1776, Dent \& Sons, London. SMITH, A. (1982), The Theory of Moral Sentiments (edited by David Daiches Raphael and Alex Lawrence Macfie: The Liberty Fund. Retrieved 12 April, 2011 from: (http:// oll.libertyfund.org/index.php? option $=$ com_staticxt\&staticfile=show.php \% 3Ftitle=192\&ltemid=27). Originally published in Glasgow and later in London: A. Millar Publisher. 
MT.

SMITH, A. (1975), Essays on Philosophical Subjects, Kessinger Publishing, Whitefish,

SMITH, D. J. (2007), A Culture of Corruption: Everyday Deception and popular Discontent in Nigeria, : Princeton University Press, Princeton and Oxford.

STANKIEWICZ, R. (1986), Academics and Entrepreneurs: Developing UniversityIndustry Relations, Frances Pinter Publishers, London.

STRAYER, G., HAIG, R. (1923), The Financing of Education in the State of New York, Macmillan, New York.

UNDIE, J. (2007), Education Governance, Tabson Global Resources, Calabar. Scotland.

University of Aberdeen (2005-09), Postgraduate prospectus, University of Aberdeen,

VESELY, D., MCCOMB, B.C., VOLTA, CD, SURING, L. H., HALAJ, J., HOITHAUSEN, R.S., ZUCKERBERG, B., MANLEY, P.M. (2006), Development of Protocols to Inventory or Monitor Wildlife, Fish, or Rare Plants, General Technical Report W0-27, US Department of Agriculture, Forest Service, Washington DC.

Initial submission, August 26, 2010

Revised submission, March 2, 2010

Final acceptance, April 28, 2011

Correspondence: Institute of Public Policy and Administration (IPPA), IPPA Building, $1^{\text {st }}$ Floor, Rm.124, University of Calabar, Calabar, Cross River State, Nigeria.

E-mail: cradle.africa@gmail.com; ingwe.richard@gmail.com 